\title{
Disruptive financial innovations: the case of Nigerian micro-entrepreneurs
}

\author{
Oluyemi Theophilus Adeosun, Ayodele Ibrahim Shittu and \\ Daniel Ugbede \\ Department of Economics, University of Lagos, Lagos, Nigeria
}

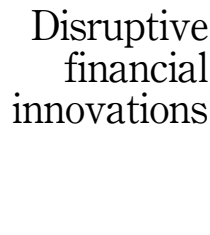

Received 30 January 2021 Revised 16 March 2021 16 March 2021

Accepted 17 March 2021

\begin{abstract}
Purpose-Despite the noticeable consequences of disruptive financial innovations, access to finance remains a major factor inhibiting the sustainable-growth potentials of young micro-entrepreneurs in informal settings. This study examines the determinants of financing options among micro-entrepreneurs in informal settings. Specifically, the study seeks to establish whether credit history, income, asset, gender, awareness and network capability have effects on formal and informal financing options among micro-entrepreneurs in informal settings.

Design/methodology/approach - This article uses the survey research design and administers a structured questionnaire among 300 purposively selected micro-entrepreneurs within the University of Lagos, Nigeria. Only 291 completed questionnaires are retrieved. This article also uses the multiple regression analysis to estimate the empirical model and test the research hypotheses respectively.

Findings - This article establishes that: (1) credit history and assets-based financing are significant determinants of formal financing options among young micro-entrepreneurs in informal settings, (2) gender and network capability are significant determinants of informal financing options among young micro-entrepreneurs in informal settings and (3) awareness is significant of both formal and informal financing options among young micro-entrepreneurs in informal settings.

Originality/value - This article examines the determinants of financing option among young microentrepreneurs in informal settings. Specifically, the study seeks to establish whether credit history income asset gender awareness and network capability have effects on formal and informal financing options among micro-entrepreneurs in informal settings.
\end{abstract}

Keywords Financial innovations, Financing options, Informal settings, Micro-entrepreneurs, Young people Paper type Research paper

\section{Introduction}

Economic and financial crises are most often considered to be a major setback for developed and developing nations alike because it erodes significant gains made at economic growth and development. The 2008-2009 global economic and financial and, recently, the 2016 global slow growth heralded the restriction of major sources of internal and external finance needed to augment investment and boost growth, particularly for developing nations (Hinson et al., 2019; Tidjani, 2020). Nevertheless, these unfavourable economic conditions

(C) Oluyemi Theophilus Adeosun, Ayodele Ibrahim Shittu and Daniel Ugbede. Published in Journal of Business and Socio-economic Development. Published by Emerald Publishing Limited. This article is published under the Creative Commons Attribution (CC BY 4.0) licence. Anyone may reproduce, distribute, translate and create derivative works of this article (for both commercial and non-commercial purposes), subject to full attribution to the original publication and authors. The full terms of this licence may be seen at http://creativecommons.org/licences/by/4.0/legalcode

We acknowledge everyone who have and will still contribute to the great success of this research work. Many thanks to the anonymous referees.

Funding: The author received no direct funding for this research work.

Conflict of interest: The authors declare no conflict of interest.

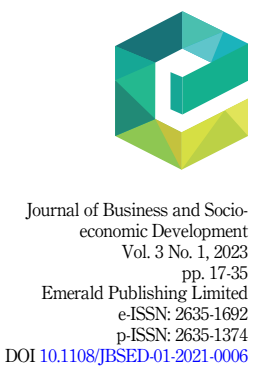


JBSED 3,1 present opportunities of disruptive natures to help developed and emerging economies create economic shock absorbers in two key areas. (Demir et al., 2020; Frost, 2020).

First, these crises have generated disruptive forces and reforms of the international financial architecture and the greater awareness of need to increase financing options or alternative for investment projects (Eguren-Martin et al., 2020). The global economic crisis of 2008 exposed the weaknesses of the traditional financial institutions and consequently led to the rise of informal financial institutions and financial start-ups (FinTech) to meet the fast-growing financial needs of the private sectors, particularly small and mediumsized enterprises (SMEs) and or micro-entrepreneurs. According to World Economic Forum (2017), these new entrant into the financial system are challenging the system, promising to swiftly redesign how financial services are structured, provisioned and consumed.

Another consequent disruptive outcome of the global economic crises, especially for developing economies, is the diversification of export markets from natural commodities to commodities that support growth and thus reduce vulnerability to external shock (AlMansour and Al-Ajmi, 2020). According to Chen et al., 2017 and Anand and Mantrala, 2019, these commodities are disruptive innovations produced by SMEs or micro-entrepreneurs. This is possible because micro-entrepreneurs tend to benefit over their economic size rivals due to ease of adjusting and withstand these economic conditions as a result of their flexible features (Dalitso and Peter, 2000; Sykes et al., 2016; Ernst and Haar, 2019). However, it is worthy to note that young micro-entrepreneurs are driving force behind this disruption due to the trend of transition of young people from informal entrepreneurship.

There is a consensus that young micro-entrepreneurs represent a chunk of businesses and engagement in the informal private sector of emerging economies of developing nations. They are the base and spine of all economies and are regarded as key components in national growth and development (Abbasi et al., 2017). Micro-entrepreneurs are often referred to as capable and effective job creators, potential large sustainable organisations and the oil of national financial machines. Young micro-entrepreneurs are advantageous over large businesses considering creation of employment, striving in developed economies (Mullineux, 1995; Padaki, 2018). Despite these potentials within the above identified opportunities, restricted access to finance or financing options is regularly mentioned as key factor inhibiting the sustainable-growth potentials of young micro-entrepreneurs in informal settings (Issa and Kiruthu, 2019).

For Nigeria, evidence of limited access to finance cannot be ignored. Of the aggregate loan of \#135.9 trillion disbursed within the period 2011-2015 in the Nigerian economy, only \#159.75 billion went to micro, small, medium enterprises (MSMEs) (CBN and IFC, 2015). Specifically, this reveals that the loans to MSMEs between these periods represent $0.1 \%$, which also commensurate with a trend of consistent decline in MSMEs financing since 2003 (Nnabugwu, 2015). This statistic then raises the questions of what are or have been the financing options of MSMEs in Nigeria (Gbandi and Amissah, 2014), and what are their determining factors?

In response to the questions of financing options, studies have it that for their lack of formal restrictions, MSMEs favour other flexible and shorts-term sources of finance such as trade credits, leasing, loan from family and friends, and informal financial sector loans, which accounts for more than $70 \%$ of the funds to the SMEs (Pavlov et al., 2004; Olugbenga et al., 2018). To support these assertions, a survey of 840 MSMEs across Nigeria revealed that a lot of MSMEs depend on alternative ways for their business financing: of the 840 microentrepreneurs, $71 \%$ finance their business through personal savings, friends and family $(14 \%)$, while others have taken loans from deposit money bank $(11 \%)$ and microfinance banks $(10 \%)$ (CBN and IFC, 2015). While substantial number of researches in Nigeria have opined that finance is a key factor to MSMEs growth, (Admasu, 2012; Evbuomwan et al., 2013; 
Small and Medium Enterprise Development Agency of Nigeria, 2013; Gbandi and Amissah, 2014; Mat, 2015), mirage empirical evidence has been provided in term of determinants of access to finance or financing options for MSMEs.

In light of this, the fundamental questions to be asked then become; what are alternative financing options available to young micro-entrepreneurs, and what factors are responsible for limited access to finance for young micro-entrepreneurs, especially in developing economy like Nigeria. The literature has expressed this question to be the determining factors that influence the financing options for micro-entrepreneurs given their limited access to formal financial services (Thorsten et al., 2007; Taiwo et al., 2016; Mhando, 2018; Palmié et al., 2020). Hence, access to finance does not necessarily mean the readiness of funds and financial institutions, but the relationship amongst access-supply and access-demand factors (Claessens, 2006; Beck and de la Torre, 2007; Tah, 2019). This study particularly focuses on the demand side.

It is observed that existing studies have identified several determinants such as: awareness, firm age, firm size, credit history, asset control, income level, education (literacy), gender, interest rates and network capability (Claessens, 2006; Beck and de la Torre, 2007, He and Baker, 2007; Korir, 2013). Specifically, these factors have been categorised into three major categories; firm characteristic, owner's characteristics and financing characteristics (Cardone and Carzola, 2001; Robb, 2002; He and Baker, 2007; Tirfe and Abera, 2014; Mhando, 2018). But empirical studies probing the outcome of these determinants on the choice of financing mechanism among micro-entrepreneurs in the informal services sector is very scanty.

This study therefore aims to identify disruptive financing alternatives for young microentrepreneurs and examine the determinants of financing options among microentrepreneurs in Nigeria's informal settings. Specifically, this study seeks to establish whether credit history, income, assets, gender, awareness and network capability have effects on formal and informal financing options among young micro-entrepreneurs in informal settings.

This study is motivated by several factors which include the lack of quantitative published data for micro-enterprises in Nigeria, and the challenges that informal enterprise face in assessing finance and the need for alternate options. The University of Lagos provides an environment that is peculiar and has access to basic amenities like electricity, and affordable rent. It is situated at the center of Lagos, the commercial hub of the country. The university has a population of about 70,000 people daily. The population of businesses owners in the university are all literate and open to research survey. Emphasis was placed on micro-entrepreneurs within the university because they provide a simple model of the nature of transaction within the broader developing economy of Nigeria.

\section{Literature review}

\subsection{Conceptual review}

Providing anecdotal accounts of the financing alternatives available to micro-enterprises is essential in the study of small business financing (Quartey et al., 2017). Information distortion, transaction cost and risk of a financing option determines micro-enterprises' ease of access to finance (Akingunola, 2011; Aabi, 2014). However, disruptive financial innovations are transformations that reduce cost, reduce risk and offer advanced financial products, services and mechanisms that better meets the financing needs of customers (Frame and White, 2004). Also known as financial start-ups, they are replacing the traditional financial intermediaries at an increasing rate because of their flexibility in determining their respective levels of risk and returns. They are also promoting access to capital, as well as satisfying the diverse "risk" appetite of high-risk borrowers through the proliferation of alternative lending platforms.

\section{Disruptive financial innovations}


JBSED 3,1

Disruptive financial innovations are propelled by new technology, new rules and changes in economic development like economic behaviours. According to Frost (2020), the impetus behind financial innovation is motivated by the maximisation of profit within a free market. While bank loans offer moderate returns for traditional financial institutions and is quite adequate for low to moderate micro-entrepreneurs, alternative financial innovations alter this conventional risk sharing mechanism (OECD, 2018). These instruments aside traditional financing options consist of multiple and competing financing options for microentrepreneurs, including asset-based financing, rotating savings and credit associations (ROSCAs), peer-to-peer lending and crowdfunding (debt and equity). However, it is important to note that not all are suitable and of interest to all micro-entrepreneurs. It therefore depends on the determinants of their financing options which includes size, stage in the business life cycle, risk-return profile, management structure and financial skills.

\subsection{Asset-based financing}

Asset-based financing is an innovative financial innovation that comprises asset-based lending, factoring, invoice discounting, warehouse receipts and leasing. This form of financing differs from conventional debt finance as micro-entrepreneurs obtain the required funding based on the value of specific assets rather than its own credit rating. Therefore, term loans and working capital are secured based on asset. Such asset includes inventory, machines and equipment, account receivable and landed properties.

According to OECD (2018), the key benefit of asset-based financing is that the microentrepreneur can obtain requisite funds under more flexible arrangements, when compared to traditional bank loans regardless of their financial positions and future cash flow potentials. Also, with asset-based finance, micro-entrepreneurs that are without required credit history or in need of cash flow to take advantage of growth opportunities have the advantage to get working capital within a shorter period even without personal guarantee from the micro-entrepreneur. However, the cost incurred to obtain such fund is usually higher than those associated with traditional bank loans.

For example, asset-based lending involves a revolving arrangement, wherein the microentrepreneur can secure additional funding through the assets of the business, like inventories and receivables. Hence, receivables are generated from new sales or inventories by the micro-entrepreneurs and these assets form part of the borrowing base. Factoring, on the other hand, is a short-term financing instrument, whereby cash is received by the microentrepreneur from a specialised third-party (factor) in exchange for its accounts receivable (debtors), which results trade sales. The factor is responsible for collecting the receivables on behalf of the micro-entrepreneur (Vasilescu, 2010). Similarly, invoice discounting helps microentrepreneurs raise business finance by keeping their outstanding invoices as collateral. Lastly, leasing is financial innovation that allows the procurement of capital equipment, in which one party (lessor) agrees to provide an asset to another party (lessee) to utilise over a fixed period of time for a specific regular payment (Abbassi et al., 2017).

\subsection{Rotating Savings and Credit Association (ROSCA)}

For most developing economies like Nigeria, micro-entrepreneurs have found solace in the traditional but evolving ROSCA as an option of utilising the abundant financing options in the informal financial sector (Aruwa, 2004). This financial innovation, established solely due to the financing constraint of formal financing institutions, has thrived in many societies where they are not less known as saving institutions and christened based on the ethnic group in Nigeria: Nsusu (Igbo), Oja (Igala), Esusu (Yoruba), Adache (Hausa), etc. Similar institutions are found in West African countries (Benin Republic and Ghana) as well as other African countries. 


\subsection{Peer-to-peer lending}

Peer-to-peer (P2P) lending and its platforms has now been considered one of the major financial innovation that minimises the credit constraints of traditional banks and financial institutions and thus meets the expanding financial needs of small businesses across the world (Rosavina and Rahadi, 2018). P2P lending is a short- and medium-term financing mechanism that link borrowers and lenders through the Internet. Here, micro-entrepreneurs supply information regarding their personal and financial conditions, while the fund provider assess the inherent risk and decides to fund these businesses based on the information provided (Galloway, 2009).

\subsection{Crowdfunding}

A more recent and in vogue financing source for micro-entrepreneurs is crowdfunding. Crowdfunding is an external financing source, whereby large number of individuals contributes small amounts of money to meet the financing needs of an individual or a business. The concept of crowdfunding can be traced to "crowd-sourcing", which is concerned with the outsourcing to the "crowd" of a peculiar task, say, the valuation or merchandise sales, by process of open call over the web (Howe, 2008). Lambert and Schweinbacher (2010) (Belleflamme et al., 2010) assert that "Crowdfunding" entails an open call via the Internet, to provide requisite funds either by contributions (without rewards) or in lieu of other form of rewards.

2.5.1 Empirical review. Evidences abound that the credit history of owner-managers influences firms' financing options (Le and Nguyen, 2009; Nguyen and Ramachandran, 2006; Borgia and Newman, 2012; Newman, 2010). In their study, Nguyen and Ramachandran (2006) uses the multinomial logistic analysis, and their findings show that access to external financing among small enterprises increases in relation to the number of successful loan repayment made to their financiers. This is inclusive of short-term debt. This demonstrates that a good credit history increases the willingness of small enterprise owners to approach banks and/or alternative financial sources for loans. Thus, the study proposes that: credit history has both positive effects on the choice of formal financing and informal financing option among micro-entrepreneurs operating in informal settings (I).

Evidences abound that the profitability (i.e. the ratio of profit before tax and interest over sales turnover) of a firm plays a significant role on their choice of financing options (Levine, 2005). High profitability firms prefer internal financing to debt financing. Chakrabory (2010) shows that such firm demands for debt or excess finance only when additional funds are necessary. Studies (i.e. Cassar and Holmes, 2003; Sogorb-Mira, 2005) have also shown a negative relationship between profitability and firm leverage. Thus, conforming to the pecking order theory. From the perspective of developing countries, the findings from Abor and Biepke (2009) and Aliero and Yusuf (2017) also show profitability level negatively affects access to credit among SMEs. Based on this premise, this study proposes that income level has a negative outcome on the choice of formal financing option and positive outcome on the choice of informal financing option among micro-entrepreneurs operating in informal settings (II).

Asset is an important determinant of access to finance, whether formal or informal (Di Patti and Dell'Ariccia, 2003). Lending depends on the value of underlying assets (Berger and Udell, 2006). Empirical findings show that a positive relationship amongst fixed asset and accessing formal finance. (Newman et al., 2013; Ayed and Zouari, 2014). Asset structure is associated with long-term formal credit positively and negatively associated with short-term informal credit (Frank and Goyal, 2009). A firm asset composition impacts on the use of debt finance. Small enterprises use informal and in-house sources of finance which does not require a fixed asset surety in the short term. (Evans and Jovanovic, 1989; Abor and Biepke, 2009;
Disruptive financial innovations 
JBSED 3,1

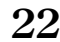

Newman et al., 2013; Mutezo, 2015). There this proposes that: asset control has a positive effect on the choice of formal financing options and negative effect on the choice of informal financing option among micro-entrepreneurs operating in informal setting (III).

Despite the inadequate empirical studies on the relationship or association between gender and financing options, particularly for micro-entrepreneurs existing researches reveal that the firm owner gender impact the capital composition mix of the firm (Chinonso and Zhen, 2016). Mijid (2009) using deceptive statistics opined that in the United State of America, firms owned by women experience a lower loan application and acceptance rate that their mail counterpart. Riding and Swift (1990) discovered that for women to secure loan, more collateral was demanded when compared to the men. Marlow and Patton (2005) propose that lender's choice is influenced by gender while selecting who to borrow loans. Orser et al. (2006) find that bank is stricter in granting loans to female managed business, thereby limiting their access to formal finance. The study further shows that bank believe female-owned businesses posse higher risk than male-owned businesses. Coleman (2000) using FEMALE as a variable to capture gender differences in the use of credit products in a logistic regression analysis revealed that there were differences between men and women in when it comes to debt finance. However, Fatoki and Asah (2011) also state that gender have no impact on the accessibility of finance by SMEs. Hence, this study adopting Coleman's use of FEMALE to capture gender difference proposes that gender has a negative relationship with formal financing options and positive relationship with informal financing options (IV).

For level of awareness defined by level of education qualification, Aliero and Yusuf (2017) and Fatoki and Asah (2011), both employing regression analysis to examine the constraints to credit access (formal and informal) in Nigeria and South Africa, respectively, assert that an entrepreneur's level of education positively and meaningfully influence lending from formal sources. Similarly, Zarook et al. (2013) confirmed this in Libya, in which the higher the level of education, the better the chance of access to formal and informal finance. Creditworthiness of a firm have been found to have a positive relationship with educational attainment and managerial experiences; they also help drive down adverse selection cost as potential financers feel more comfortable with them. (Storey, 1994; Bates, 1997; Cassar, 2004; Zhang, 2008). Thereby persuading the bank with their practical propositions (Othman et al., 2006; Scott and Irwin, 2009; Wu et al., 2008). This study therefore proposes that education/level of awareness has a positive relationship with both formal and informal financing options (V).

In terms of the impact of networking capability on financing options, Kapkiyai and Kimitei (2016), using both descriptive statistics and statistical analysis, examined the effect of SMEs owner's social network on capital structure. The study found out that social network had both positive and significant effect on capital structure of small firms. Likewise, Chinonso and Zhen (2016) employing logistic regression analysis found out that entrepreneur's networking significantly influenced financing options of SMEs in Nigeria. Even more, Nguyen and Luu (2013) investigating the determinants of financing patterns and access to finance found that social network and official network proved to significantly improve SMEs ability to access bank and other sources of capital in Vietnam. Hence, the study proposes that networking has a positive relationship with both formal and informal financing options (VI).

\section{Methods}

For us to determine the impact of these determinants on the financing options of microentrepreneurs, this study adopts the survey research design. Quantitative data were collected through a structured questionnaire distributed to 300 conveniently sampled microentrepreneurs in the University of Lagos. The survey yielded 291 valid questionnaires deemed as useable respondents. The questionnaire made use of Likert scale measure, a fifteen 
Likert-like scale having five response categories weighted as very great extent (5) great extent (4) some extent (3) little extent (2) very little extent (1). A reliability test is carried out to determine the internal consistency of each item of the measuring instrument- the questionnaire.
Disruptive financial innovations

\subsection{Econometric model}

Empirically, we aim to study the influence of credit history, income level, asset control, gender, awareness and networking on financing options (formal and informal) as dependent variables. To test these relationships, we considered the following model.

$$
\begin{aligned}
Y_{i}= & {\left[\frac{\mathrm{FFO}_{i}}{\mathrm{FO}_{i}}\right] } \\
= & \alpha_{0}+\beta_{1} \mathrm{CREDIT} \cdot \mathrm{H}+\beta_{2} \mathrm{INCOME}+\beta_{3} \mathrm{ASSETCTRL}+\beta_{4} \mathrm{FEMALE} \\
& +\beta_{5} \mathrm{EDUCATION}+\beta_{6} \mathrm{NETWORK}+\varepsilon_{i}
\end{aligned}
$$

Similarly,

$$
\begin{aligned}
\mathrm{FFO}_{i}= & \alpha_{0}+\beta_{1} \mathrm{CREDIT} \cdot \mathrm{H}+\beta_{2} \mathrm{INCOME}+\beta_{3} \text { ASSETCTRL }+\beta_{4} \text { FEMALE } \\
& +\beta_{5} \text { EDUCATION }+\beta_{6} \text { NETWORK }+\varepsilon_{i} \\
\text { IFO }_{i}= & \alpha_{0}+\beta_{1} \text { CREDIT.H }+\beta_{2} \text { INCOME }+\beta_{3} \text { ASSETCTRL }+\beta_{4} \text { FEMALE } \\
& +\beta_{5} \text { EDUCATION }+\beta_{6} \text { NETWORK }+\varepsilon_{i}
\end{aligned}
$$

where $Y_{i}$ is a column vector of financing options proxy as formal financing options (FFOs) and informal financing options (IFOs), $\alpha_{0}=$ intercept, $\beta_{1-6}=$ slope, $i=$ number of financing options and $\varepsilon=$ error term.

Credit history refers to the relationship between the micro-entrepreneur and the lender bank and non-bank lenders (Nawi, 2015). It is usually measured as the number of loans and services taken by the borrower and successfully repaid. Income level refers to the enterprise profitability measured by the ratio of profit before tax and interest over sales turnover. Gender refers to a socially constructed set of roles and responsibilities associated with being male or female. Level of awareness refers to the amount of knowledge or information an individual possesses about a thing or subject (Nguyen and Ramachandran, 2006). Asset Control refers to the size, nature and ownership of asset in possession of micro-entrepreneur.

Equation (1) shows the functional relationship between financing options and the determinants of financing options. Specifically, Eqs. (2) and (3) show the functional relationship between formal financing options and determinants of financing options, and the functional relationship between informal financing options and determinants of financing options, respectively. To investigate this model, the multiple regression analysis was employed to ascertain the relationship between the identified independent variables and the dependent variables of formal and informal financing options.

3.1.1 Reliability test. The questionnaire was subjected to reliability test for us to determine how reliable our questionnaire is, with the Cronbach alpha result determining how reliable the questions are. Six factors were put to test, and the Cronbach alpha coefficient ranged between 0.643 and 0.736 , which suggests high reliability (see Table 1).

\subsection{Multiple regression analysis}

3.2.1 Model summary (formal financing). The result from multiple regression analysis for formal financing is presented in Table 2. Overall, the model was found to be significant at 


\begin{tabular}{|c|c|c|c|c|c|c|}
\hline $\begin{array}{l}\text { JBSED } \\
3,1\end{array}$ & $\underline{\text { Item }}$ & Mean & $\mathrm{SD}$ & $\begin{array}{c}\text { Corrected item }- \text { total } \\
\text { correlation }\end{array}$ & $\begin{array}{l}\text { Cronbach's alpha if item } \\
\text { deleted }\end{array}$ & $\begin{array}{c}\text { Total Cronbach's } \\
\text { alpha }\end{array}$ \\
\hline & \multicolumn{5}{|c|}{ Credit history } & \multirow[t]{11}{*}{0.720} \\
\hline & Q16a & 3.90 & 1.153 & 0.379 & 0.699 & \\
\hline & Q16b & 3.90 & 0.952 & 0.530 & 0.675 & \\
\hline & Q16c & 3.58 & 0.941 & 0.359 & 0.701 & \\
\hline \multirow{43}{*}{24} & Q16d & 3.74 & 0.859 & 0.417 & 0.694 & \\
\hline & Q16e & 3.36 & 0.956 & 0.297 & 0.711 & \\
\hline & Q16f & 3.57 & 1.194 & 0.429 & 0.690 & \\
\hline & Q16g & 2.95 & 1.062 & 0.302 & 0.711 & \\
\hline & Q16h & 3.38 & 1.087 & 0.457 & 0.685 & \\
\hline & Q16i & 2.28 & 0.995 & 0.248 & 0.718 & \\
\hline & Q16j & 2.75 & 1.032 & 0.393 & 0.696 & \\
\hline & \multicolumn{5}{|c|}{ Income level } & \multirow{7}{*}{0.643} \\
\hline & Q19a & 2.31 & 1.127 & 0.493 & 0.601 & \\
\hline & Q19c & 3.90 & 0.952 & 0.265 & 0.615 & \\
\hline & Q19e & 2.20 & 1.216 & 0.479 & 0.503 & \\
\hline & Q19f & 3.74 & 0.859 & 0.380 & 0.619 & \\
\hline & Q19g & 2.26 & 1.379 & 0.551 & 0.631 & \\
\hline & Q19h & 3.38 & 1.303 & 0.529 & 0.543 & \\
\hline & \multicolumn{5}{|l|}{ Assets } & \multirow[t]{11}{*}{0.736} \\
\hline & Q21f & 2.33 & 1.377 & 0.534 & 0.691 & \\
\hline & Q21g & 2.61 & 1.475 & 0.540 & 0.689 & \\
\hline & Q21h & 3.33 & 1.321 & 0.402 & 0.714 & \\
\hline & Q21i & 3.57 & 0.949 & 0.206 & 0.738 & \\
\hline & Q21j & 3.04 & 1.252 & 0.141 & 0.753 & \\
\hline & Q21k & 3.23 & 1.113 & 0.228 & 0.738 & \\
\hline & $\mathrm{Q} 21 \mathrm{~m}$ & 1.61 & 1.101 & 0.465 & 0.706 & \\
\hline & Q21n & 1.78 & 1.098 & 0.479 & 0.704 & \\
\hline & Q21o & 1.65 & 1.108 & 0.485 & 0.703 & \\
\hline & Q21p & 1.82 & 1.345 & 0.479 & 0.701 & \\
\hline & \multicolumn{5}{|c|}{ Awareness } & \multirow[t]{10}{*}{0.653} \\
\hline & Q22a & 3.40 & 1.020 & 0.353 & 0.620 & \\
\hline & Q22b & 3.59 & 0.954 & -0.219 & 0.730 & \\
\hline & Q22c & 3.57 & 1.026 & 0.274 & 0.638 & \\
\hline & Q22d & 3.12 & 0.957 & 0.430 & 0.604 & \\
\hline & Q22e & 3.21 & 1.100 & 0.397 & 0.609 & \\
\hline & Q22f & 2.86 & 1.160 & 0.433 & 0.599 & \\
\hline & Q22g & 3.30 & 0.926 & 0.295 & 0.633 & \\
\hline & Q22h & 3.17 & 1.016 & 0.489 & 0.589 & \\
\hline & Q22i & 3.38 & 1.084 & 0.557 & 0.568 & \\
\hline & \multicolumn{5}{|c|}{ Network capability } & \multirow[t]{10}{*}{0.712} \\
\hline & Q22a & 3.47 & 1.121 & 0.269 & 0.702 & \\
\hline & $\mathrm{Q} 22 \mathrm{~b}$ & 3.56 & 0.989 & 0.332 & 0.696 & \\
\hline & $\mathrm{Q} 22 \mathrm{c}$ & 3.49 & 1.005 & 0.282 & 0.701 & \\
\hline & Q22d & 3.47 & 1.061 & 0.177 & 0.711 & \\
\hline & Q22e & 3.42 & 1.088 & 0.277 & 0.701 & \\
\hline & Q22f & 3.41 & 0.921 & 0.233 & 0.705 & \\
\hline & Q22g & 3.36 & 1.042 & 0.165 & 0.712 & \\
\hline \multirow{2}{*}{$\begin{array}{l}\text { Table 1. } \\
\text { Reliability test }\end{array}$} & Q22h & 3.90 & 1.153 & 0.407 & 687 & \\
\hline & \multicolumn{5}{|c|}{ Source(s): Compiled by the authors } & \\
\hline
\end{tabular}

$95 \%$ level of significance $(\phi<5)$ with $R^{2}$ value $=0.527$ and adjusted $R^{2}$ value $=0.481$, which are acceptable threshold for the model. Similar result was found in Fatoki (2011).

We check for auto correlation in the data used by conducting the Durbin Watson test. The result of 1.954 shows that there is no correlation among the variables in the data as the value 
is close to the ideal value of 2 . The result further shows high level of independence among the variables used in the model.

3.2.2 Standardised coefficient. The variance inflation factor (VIF) analysis was conducted to determine the level of multi-collinearity among the variables in Table 3; the result shows that the VIF are within the accepted threshold 3.3 (e.g. Petter et al., 2007), hence lack of multicollinearity.

The importance of the dependent variables to the independent variables is explained by Betas (Tabachnik and Fidell, 2007). The values further represent the degree of responsiveness of the dependent variables to the independent variables. With $95 \%$ level of confidence with a $p$-value smaller than 0.05 , the multiple regression was found to be significant. Three variables were found to have statistical and significant contributions (less than 0.05$)$ (Table 3$)$. They are asset $(\beta=0.237)$, awareness $(\beta=0.119)$ and credit history $(\beta=0.210)$ in order of importance.

The derived relationship between the determinants of financing options are formal financing options are shown in Table 4.

\subsection{Model summary (informal financing)}

Multiple regression analysis for informal financing is shown in Tables 5 and 6 . The model was significant at $95 \%$ level of significance $(\phi<0.05) . R^{2}=0.696$ and adjusted $R^{2}$ value $=0.512$, with Durbin Watson score of 1.908 which is close to 2 hence no auto correlation. The $p$-value is less than 0.05 hence is significant as shown in Table 5 .

3.3.1 Standardised coefficient. The outcome of the VIF analysis (Table 6) shows that the VIF values all the variables examined do not surpass the threshold generally accepted (3.3), which imply that no multi-collinearity problems exist with the variables. There are four variables that make a statistically significant contribution (less than 0.05 ) (see Table 6). In order of importance, they are awareness $(\beta=178)$, gender $(\beta=0.246)$, network $(\beta=-0.141)$ and income $(\beta=0.218)$.

\section{Discussion of results}

We classify our discursion into six main groups in line with the hypotheses of the study.

\section{$4.1 \mathrm{H1}$ : enterprise credit history has no significant impact on financing options among micro-entrepreneurs in the University of Lagos}

Based on the existing literature and the proposition deduced in the study that credit history has a positive relationship with both formal and informal financing options, the result of the formal financing options model (model 1) tested using the estimation techniques adopted confirms that credit history has a positive and significant impact on formal financing options such as bank loan, microfinance loans and government schemes. Multiple regression result

\begin{tabular}{|c|c|c|c|c|c|c|c|c|c|c|}
\hline \multicolumn{11}{|c|}{ Model summary } \\
\hline Model & $R$ & $R^{2}$ & $\begin{array}{l}\text { Adjusted } \\
R^{2}\end{array}$ & $\begin{array}{c}\text { SE of } \\
\text { estimate }\end{array}$ & $\begin{array}{c}R^{2} \\
\text { change }\end{array}$ & $\begin{array}{l}\text { Chang } \\
F \\
\text { change }\end{array}$ & $\begin{array}{l}\text { stati } \\
\text { df1 }\end{array}$ & & $\begin{array}{l}\text { Sig. } F \\
\text { change }\end{array}$ & $\begin{array}{l}\text { Durbin } \\
\text { Watson }\end{array}$ \\
\hline 1 & 0.766 & 0.527 & 0.481 & 0.86126 & 0.478 & 46.954 & 6 & 284 & 0.000 & 1.954 \\
\hline
\end{tabular}

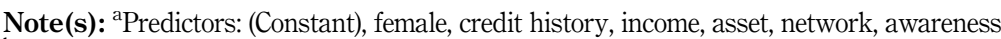
${ }^{b}$ Dependent variable: formal financing options

Source(s): Compiled by the authors
Disruptive financial innovations 
JBSED

3,1

\section{6}

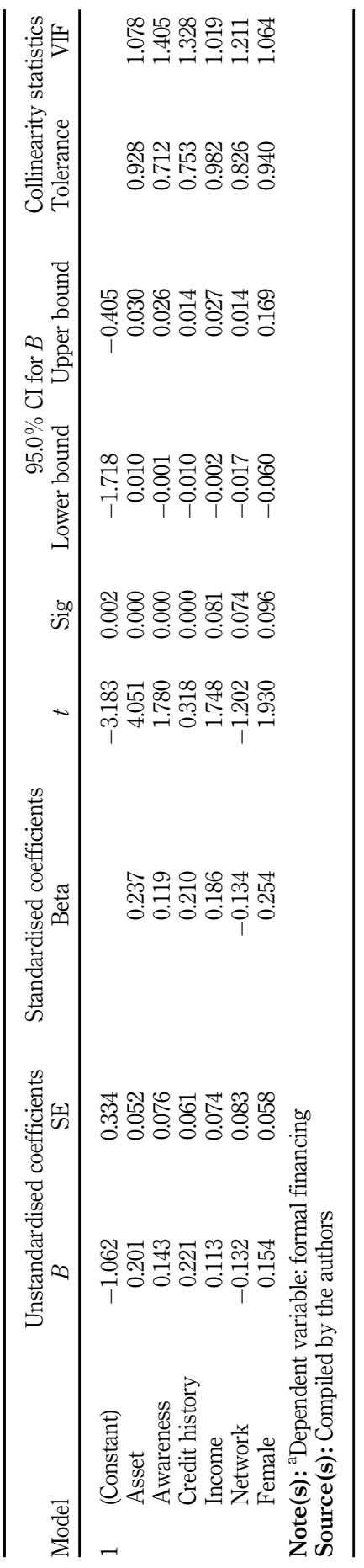

Table 3.

Standardised coefficient (formal financing) 
Proposition Predictor

I CREDIT HISTORY has a positive and significant impact on formal financing options $(\phi=0.000, \beta=0.221)$

II INCOME has a positive and insignificant impact on formal financing options $(p=0.081, \beta=0.186)$

III ASSET has a positive and significant impact on formal financing options $(p=0.000, \beta=0.201)$

IV FEMALE has a positive and insignificant impact on formal financing options $(p=0.096, \beta=0.254)$

$\mathrm{V} \quad$ AWARENESS has a positive and significant impact on formal financing options $(p=0.00, \beta=0.143)$

VI NETWORK has a negative and insignificant impact on formal financing options $(p=0.740, \beta=-0.132)$

Source(s): Compiled by the authors

\section{Disruptive financial innovations}

Not

supported

Supported

Not

supported

Supported

Not

supported
Table 4.

Factors that influence formal financing options among microentrepreneurs

\begin{tabular}{lcccccccccc}
\hline Model summary & \multicolumn{11}{c}{} & \multicolumn{1}{c}{ Adjusted } & $\begin{array}{c}\text { SE of } \\
\text { Model }\end{array}$ & $R$ & $R^{2}$ & $R^{2}$ & $R^{2}$ & \multicolumn{2}{c}{$\begin{array}{c}F \\
\text { estimate }\end{array}$} & change & change & df1 & df2 & $\begin{array}{c}\text { Sig. } F \\
\text { change }\end{array}$ & $\begin{array}{c}\text { Durbin } \\
\text { Watson }\end{array}$ \\
\hline 1 & 0.824 & 0.696 & 0.512 & 0.64825 & 0.398 & 35.624 & 6 & 284 & 0.000 & 1.908
\end{tabular}

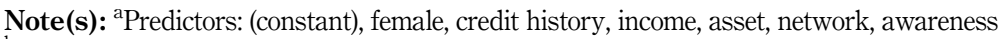

${ }^{b}$ Dependent variable: formal financing options

Source(s): Compiled by the authors

Table 5.

Model summary (informal financing)

indicates that with a positive and significant $(p<0.05)$ coefficient of 0.221 , credit history increased the use of formal financing by about $22 \%$. Hence, reject the null hypothesis for formal financing options.

However, in terms of informal financing option, test results do not support the proposition of a positive and significant influence. This is evident in Table 6, where credit history has a negative and insignificant association $(\phi=0.234, \beta=-0.142)$ with informal financing. Thus, we accept the null hypothesis for informal financing options.

\subsection{H2: enterprise income level has no significant impact on financing options among micro- entrepreneurs in the University of Lagos}

Based on the proposition that: income level is negatively related to both formal and informal financing options. Test result indicate otherwise for both formal and informal financing options, our estimation technique show a positive but insignificant coefficient $(B=0.186$ and $p=0.081)$ for formal financing options. In the case of the informal financing model, regression results (Table 6 ) yields $(\beta=0.160$ and $p=0.280$ ) and thus imply a positive but insignificant relationship between income level and both financing options. Hence, we accept the null hypothesis for both financing options.

\subsection{H3: enterprise asset control has no significant impact on financing options among micro-} entrepreneurs in the University of Lagos

The proposition that asset has a positive relationship with formal financing options and negative relationship with informal financing options is only supported by the formal 
JBSED

3,1

\section{8}

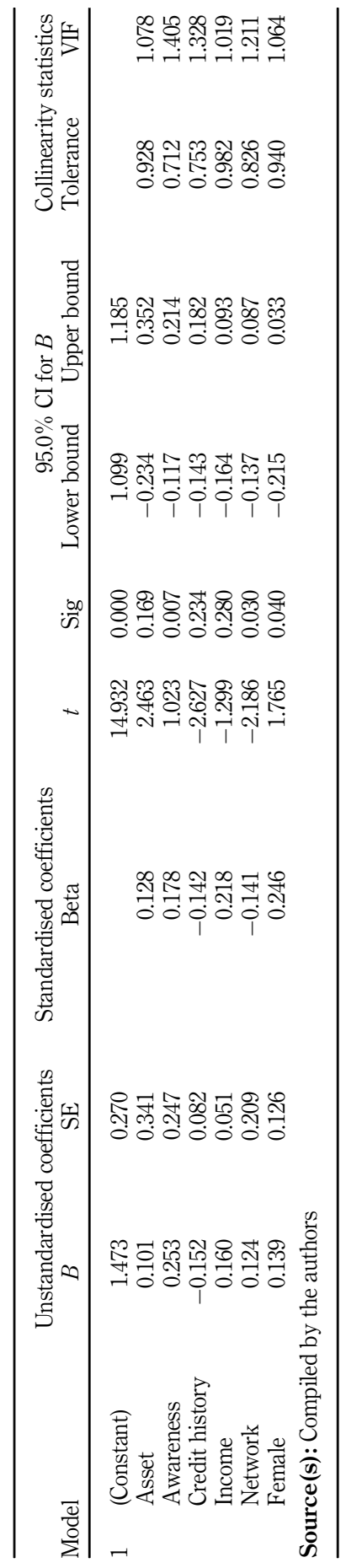

Table 6.

Standardised coefficient (informal financing) 
financing model that yields a positive and significant coefficient as expected $(B=0.201$ and $p=0.000$ ), indicating a positive relationship between assets and formal financing options. Hence, reject the null hypothesis for formal financing options. However, in the case of the informal financing model, where asset has a positive but insignificant influence on informal financing options, $B=0.101, p$-value is 0.169 . Thus, we accept the null hypothesis for informal financing options.

\subsection{H4: gender has no significant impact on financing options among micro-entrepreneurs} in the University of Lagos

Given the proposition that FEMALE has a negative relationship with formal financing option and positive relationship with informal financing option, test results do not affirm the proposition made for formal financing. However, the model yields a positive and insignificant influence of gender on formal financing with $B=0.254, p=0.096$. This indicates that as female entrepreneurs increase, the less likely they are to choose formal financing options. We accept the null hypothesis for formal financing options.

In the case of informal financing model, the proposition is supported, where FEMALE has a positive and significant influence on informal financing options. $B=0.139, p$-value is 0.000 , which also suggest that female entrepreneurs increase the more likely they would choose informal financing options. Thus, we reject the null hypothesis for informal financing options.

\subsection{H5: awareness level has no significant impact on financing options among micro- entrepreneurs in the University of Lagos}

The proposition that level of awareness has a positive relationship with both formal and informal financing options is confirmed by both formal and informal financing models tested by the study. For formal financing, its model yields a positive and significant influence as expected $(B=0.143$ and $p=0.000)$. This indicates that as entrepreneur's awareness increase the more likely he/she will choose formal financing options.

In the informal financing model, test results suggest that awareness also has a positive effect on the use of informal financing options in that $B=0.253, p=0.000$. This implies that as entrepreneur's awareness increase the more likely he/she will choose formal financing options. We therefore reject the null hypothesis and accept the alternative hypothesis.

4.5.1 H6: network capability has no significant impact on financing options among microentrepreneurs in the University of Lagos. Given the proposition that NETWORKING has a positive relationship with both formal and informal financing options, tests results does not affirm the proposition made for formal financing. The formal financing model yields a negative and insignificant influence of entrepreneurs networking on formal financing, with $B=-0.132, p=0.740$. This indicates that as entrepreneurs networking increase, the less likely they are to choose formal financing options. We thus accept the null hypothesis for formal financing options.

However, in the case of informal financing model, the proposition is confirmed, where NETWORKING has a positive and significant influence on informal financing options. $B=0.124, p$-value is $0.030(p<0.05)$, which suggest that as entrepreneurs networking increase the more likely they also choose informal financing options. Thus, we reject the null hypothesis for informal financing options.

\section{Conclusion}

The overall objective of this study is to examine the determinants of financing options among micro-entrepreneurs in the informal services sector within the University of Lagos with particular interest in establishing whether these determinants are significance in their choice 
JBSED 3,1

of access to finance. Specifically, the study pursed the goals of examining the effects determinants such as credit history, income level, asset, gender, awareness and network capability of micro-entrepreneurs have on access to finance.

\subsection{Summary of findings}

The findings are therefore summarised as follows:

(1) Credit history has a significant and positive impact of formal financing options and insignificant effect on informal financing options

(2) The income level of micro-entrepreneurs has insignificant effects on both formal and informal financing options

(3) The assets of micro-entrepreneurs have positive and significant effect on formal financing options but insignificant effect on informal financing options

(4) Gender (Female) has significant effect only on informal financing options of microentrepreneurs.

(5) Awareness has a positive and significant effect on both formal and informal financing options of micro-entrepreneurs

(6) Network capability of micro-entrepreneurs has significant effect only on informal financing options and none of formal financing options.

\subsection{Contribution of the study}

Given the fact that the quality of financing decision taken by micro-entrepreneurs are enormously crucial for the survival of their enterprises as well as the role that quality information plays in their decision-making, the results suggest that for micro-entrepreneurs and small business alike can take proactive initiatives to develop strong network ties like becoming members of strategic associations that would guarantee low-cost access to finance. In addition, small businesses can share their data and repayment history, this help to provide better assessments of lending risks.

Even though not entirely in their control, micro-entrepreneurs should recognise income and/or profitability as a sustainable means of access to finance and management of loans. This entails developing a habit of conscious business management skills that ensures the profitability of their enterprises. For instance, micro-entrepreneurs can assess the consequences that their control and risk aversion might have on their ability to grow, competitive and profitable.

The findings that about $92.1 \%$ of the respondents indicated to have never used government scheme in their enterprise, brings into question the accessibility of government funds like the Small and Medium equity investment scheme (SMEEIS), the Small and Medium Enterprises Credit Guarantee Scheme (SMECGS), the Agricultural Credit Guarantee Scheme Fund (ACGSF) and the Bank of Industry (BOI) in the Nigerian case. However, efforts should be made to adequately enlighten micro-entrepreneurs of the availability of low-cost scheme aimed at boosting their economic activities, particularly in Nigeria. Access to finance relies on macroeconomic factors like interest rate and inflation that affects the economic performance of micro-entrepreneurs. Hence, fiscal and monetary policies that ultimately reduce interest rates, stabilise inflation and boost investment should be implemented.

Although this work is a demand side study, recommendation can be made to traditional lending institutions. As financial disrupters have successfully reshaped the financial system through their data driven lending, traditional can choose to remain dogged at their regular practices or take a leap towards the FinTech revolution. Own digital effort or partnering with giant FinTech companies who can help in designing channels for data collection from 
customers can be put in place; this will further help in making better financial decisions. Placing greater weight on other factors such as the viability of its future business plans or growth potential of the firm can be considered by financial institutions. They might also consider accepting more items as collateral (i.e. other than fixed assets such as receivables, inventory and equipment) as suggested by Fagan and Zhao (2009).

\subsection{Limitations of the study and recommendations for further studies}

The non-availability of borrower specific data on the amount of credit accessed from the banks by micro-entrepreneurs is the main limitation of the study due to confidentiality reasons. To overcome this challenge, the study used survey data based on the opinions microentrepreneurs and managers. In addition, the survey was limited due to its accessibility and proximity to the researcher as well as it being a typical hub of the informal sector economy. However, this sampled area was considered enough to generalise the results for smaller economies with similar circumstances. Also, all data were gathered at a specific time, thus the variables, responses and findings may be limited to that point in time.

Although this study promotes the understanding of the impact of these on credit history, income and asset, level of awareness and network capability on the choice of financing options much work remains for future research. Notably, the study could be extended to a larger sample area or reduced to a particular industry or group of businesses. With the importance of SME sector to development of an economy, government influence in the sector could also be investigated. Further research can be undertaken to understand the effect of risk taking, entrepreneurial orientation, location of enterprise and ethnicity. Another research angle would be to focus on the effects of micro-entrepreneurs bank relationship on microentrepreneur financing. Another research perspective could be to make the study a supplyside analysis that would attempt to examine the determinants of SMEs financing.

\section{References}

Aabi, M. (2014), "The pecking order theory and SMEs financing: insight into the Mediterranean area and a study in the Moroccan context", International Journal of Euro-Mediterranean Studies, Vol. 7 No. 2, pp. 189-206.

Abbasi, W.A., Wang, Z. and Abbasi, D.A. (2017), "Potential sources of financing small and medium enterprises (SMEs) and role of government supporting SMEs", Journal of Small Business and Enterprise Development, Vol. 5 No. 2, pp. 39-47.

Abbassi, P., Brownlees, C., Hans, C. and Podlich, N. (2017), "Credit risk interconnectedness: what does the market really know?", Journal of Financial Stability, Vol. 29, pp. 1-12.

Abor, J. and Biepke, N. (2009), "How do we explain the capital structure of SMEs in Sub-Saharan Africa? Evidence from Ghana”, Journal of Economic Studies, Vol. 36 No. 1, pp. 83-97.

Admasu, A. (2012), "Factors affecting the performance of micro and small enterprises in Arada and Lideta sub-cities, Addis Ababa”, Doctoral dissertation, Addis Ababa University.

Akingunola, R.O. (2011), "Small and medium scale enterprises and economic growth in Nigeria: an assessment of financing options", Pakistan Journal of Business and Economic Review, Vol. 2 No. 1, pp. 78-97.

Al-Mansour, J.F. and Al-Ajmi, S.A. (2020), “Coronavirus' COVID-19'-supply chain disruption and implications for strategy, economy, and management", The Journal of Asian Finance, Economics, and Business, Vol. 7 No. 9, pp. 659-672.

Aliero, I.H. and Yusuf, M.M. (2017), "Analysis of constraints to credit access for SMEs in Sokoto metropolis", Asian Journal of Economic Modelling, Vol. 5 No. 2, pp. 167-174.

Anand, D. and Mantrala, M. (2019), "Responding to disruptive business model innovations: the case of traditional banks facing fintech entrants", Journal of Banking and Financial Technology, Vol. 3 No. 1, pp. 19-31. 
JBSED 3,1

Aruwa, S.A.S. (2004), "Financing options for small and medium-scale enterprises in Nigeria", The Nigerian Journal of Accounting and Research, Department of Accounting, Vol. 1 No. 2, pp. 1-15.

Ayed, W.H.B. and Zouari, S.G. (2014), "Capital structure and financing of SMEs: the Tunisian case", International Journal of Economic and Finance, Vol. 6 No. 5, p. 96.

Bates, T. (1997), "Financing small business creation: the case of Chinese and Korean immigrant entrepreneurs", Journal of Business Venturing, Vol. 12 No. 2, pp. 109-124.

Beck, T. and de la Torre, A. (2007), Analytics of Access to Financial Services, Open Access Publications. Tilburg University, Tilburg.

Belleflamme, P., Lambert, T. and Schwienbacher, A. (2010), "Crowdfunding: an industrial organization perspective”, Prepared for the Workshop Digital Business Models: Understanding Strategies, held in Paris on June, pp. 25-26.

Berger, A. and Udell, G. (2006), "A more complete framework of SMEs finance”, Journal of Banking and Finance, Vol. 30 No. 11, pp. 2945-2966.

Borgia, D. and Newman, A. (2012), "The influence of managerial factors on the capital structure of small and medium-sized enterprises in emerging economies: evidence from China”, Journal of Chinese Entrepreneurship, Vol. 4 No. 3, pp. 180-205.

Cardone, C.R. and Carzola, L.P. (2001), "How theory meets practice: an analysis of the capital structure of Spanish SMEs", The Journal of Entrepreneurial Finance, Vol. 11 No. 2, pp. 73-94.

Cassar, G. (2004), "The financing of business start-ups", Journal of Business Venturing, Vol. 19 No. 2, pp. 261-283.

Cassar, G. and Holmes, S. (2003), "Capital structure and financing of SMEs: Australian evidence", Journal of Accounting and Finance, Vol. 43, pp. 123-147.

CBN and IFC (2015), "The Credit Crunch: how the use of movable collateral and credit reporting can help finance inclusive economic growth in Nigeria", available at: https:/www.cbn.org.ng/creditcrunch.

Chakrabory, I. (2010), "Capital structure in an emerging stock market: the case of India", Research in International Business and Finance, Vol. 24 No. 3, pp. 295-314.

Chen, J., Zhu, Z. and Zhang, Y. (2017), "A study of factors influencing disruptive innovation in Chinese SMEs", Asia Journal of Technology Innovation, Vol. 25 No. 1, pp. 140-157.

Chinonso, O.K. and Zhen, T. (2016), "The influence of entrepreneurial characteristics on small and medium-sized enterprise accessibility to debt finance in Nigeria”, International Journal of Managerial Studies and Research, Vol. 4 No. 10, pp. 83-92.

Claessens, S. (2006), "Access to financial services: a review of the issues and public policy objective", The World Bank Research Observer, Vol. 21 No. 2.

Coleman, S. (2000), "Access to capital and terms of credit: a comparison of men- and women-owned small businesses”, Journal of Small Business Management, Vol. 38, pp. 37-52.

Dalitso, K. and Peter, Q. (2000), The Policy Environment for Promoting Small and Medium Sized Enterprises in Ghana and Malawi, University of Manchester.

Demir, A., Pesqu-Cela, V., Altunbas, Y. and Murinde, V. (2020), "Fintech, financial inclusion and income inequality: a quantile regression approach", The European Journal of Finance. doi: 10. 1080/1351847X.2020.1772335.

Di Patti, E.B. and Dell'Ariccia, G. (2003), Bank Competition and Firm Creation, Temi di discussiione (Economic working papers) 481, Economic Research and International Relations Area, Bank of Italy.

Eguren-Martin, F., Joy, M., Maurini, C., Moro, A., Nispi Landi, V., Schiavone, A. and van Hombeeck, C. (2020), "Capital flows during the pandemic: lessons for a more resilient international financial architecture", Bank of England Financial Stability Paper, Vol. 45 No. 589, pp. 1-56.

Ernst, R. and Haar, J. (2019), Globalization, Competitiveness, and Governability: The Three Disruptive Forces of Business in the 21st Century, Springer. 
Evans, D. and Jovanovic, B. (1989), "An estimated model of entrepreneurial choice under liquidity constraints", Journal of Political Economy, Vol. 97, pp. 808-827.

Evbuomwan, G.O., Ikpi, A.E., Okoruwa, V.O. and Akinyosoye, V.O. (2013), "Sources of finance for micro, small and medium enterprises in Nigeria", 19th International Farm Management Congress, SGGW, Warsaw, Poland.

Fagan, M. and Zhao, S. (2009), "SME financing in China: the current situation, problems and possible solutions", International Journal of Entrepreneurship and Small Business, Vol. 8 No. 2, pp. 171-185.

Fatoki, O. and Sah, F. (2011), "The impact of firm and entrepreneurial characteristics on access to debt finance by SMEs in King Williams Town, South Africa”, International Journal of Business and Management, Vol. 6 No. 8.

Frame, S. and White, L. (2004), Empirical Studies of Financial Innovation: Lots of Talk, Little Action?, American Economic Association, United States of America.

Frank, M.Z. and Goyal, V.K. (2009), "Capital structure decisions: which factors are reliably important?”, Journal of Financial Management, Vol. 38, pp. 1-37.

Frost, J. (2020), “The economic forces driving FinTech adoption across countries”, The Technological Revolution in Financial Services: How Banks, FinTechs, and Customers Win Together, p. 70.

Galloway, I. (2009), "Peer-to-peer lending and community development finance", Community Investments, Vol. 21 No. 3, pp. 19-23.

Gbandi, E.C. and Amissah, G. (2014), "Financing options for small and medium enterprises (SMEs) in Nigeria”, European Scientific Journal, Vol. 10, pp. 327-340.

He, W. and Baker, H.K. (2007), "Small business financing: survey evidence in West Texas", The Journal of Entrepreneurial Finance, Vol. 12 No. 1, pp. 27-54.

Hinson, R., Lensink, R. and Mueller, A. (2019), "Transforming agribusiness in developing countries: SDGs and the role of FinTech", Current Opinion in Environmental Sustainability, Vol. 41, pp. 1-9.

Howe, J. (2008), Crowdsourcing: How the Power of the Crowd Is Driving the Future of Business, Random House.

Issa, A.G. and Kiruthu, F. (2019), "Effect of youth enterprise development fund on the performance of youth enterprises in Marsabit County, Kenya", International Academic Journal of Law and Society, Vol. 1 No. 2, pp. 138-164.

Kapkiyai, C. and Kimitei, E. (2016), "Small and Micro enterprise Owners' Characteristics and their impact on capital structure", European Journal of Business, Economics and Accountancy, Vol. 4 No. 3, pp. 1-13.

Korir, J.C. (2013), "Challenges Facing Women Entrepreneurs in Sotik Sub-county in Bomet County", Doctoral dissertation, University of Nairobi.

Lambert, T. and Schwienbacher, A. (2010), "An empirical analysis of crowdfunding”, available at: $\mathrm{http}: / /$ ssrn.com/abstract $=1578175$.

Le and Nguyen, T.V. (2009), "The impact of networking on bank financing: the case of small and mediumsized enterprises in Vietnam", Entrepreneurship Theory and Practice, Vol. 33 No. 4, pp. 967-887.

Levine, R. (2005), "Finance and growth: theory, evidence and mechanisms", in Aghion, P. and Durlauf, S. (Eds), Handbk of Economic Growth, North Holland and Elsevier Publishers, Amsterdam.

Marlow, S. and Patton, D. (2005), "All credit to men? Entrepreneurship, finance and gender", Entrepreneurship Theory and Practie, Vol. 29 No. 6, pp. 717-735.

Mat, N.H. (2015), "Determinants of capital structure in small and medium sized enterprises in Malaysia”, Doctoral dissertation, Brunel University, London.

Mhando, P.C. (2018), "Managing in the informal economy: the informal financial sector in Tanzania", Africa Journal of Management, Vol. 4 No. 3, pp. 282-305.
Disruptive financial innovations 
JBSED 3,1
Mijid, N. (2009), Gender, Race and Credit Rationing of Small Businesses: Empirical Evidence from the 2003 Survey of Small Business Finances, Colorado State University.

Mullineux, A.W. (1995), "Banking sector restructuring, debt consolidation and small and mediumsized enterprises in transitional economies", Debt Consolidation and Small and Medium-Sized Enterprises in Transitional Economies.

Mutezo, A.T. (2015), "Small and medium enterprise financing and credit rationing: the role of banks in South Africa", Doctoral dissertation, University of South Africa.

Nawi, H. (2015), "Determinants of capital structure in small and medium sized enterprises in Malaysia”, Doctoral dissertation, Brunel University London.

Newman, A. (2010), Capital Structure Determinants of Private Small and Medium-Sized Enterprises in China, Doctoral Dissertation, University of Nottingham.

Newman, A., Gunessee, S. and Hilton, B. (2013), "Applicability of financial theories of capital structure to the Chinese cultural context: a study of privately owned SMEs", International Small Business Journal, Vol. 30 No. 1, pp. 65-83.

Nguyen, N. and Luu, N. (2013), "Determinants of financing pattern and access to formal-informal credit: the case of small and medium sized enterprises in Viet Nam", Journal of Management Research, Vol. 5 No. 2, pp. 1-22, 1941-899X 2013.

Nguyen, T.D.K. and Ramachandran, N. (2006), "Capital structure in small and medium-sized enterprises: the case of Vietnam", ASEAN Economic Bulletin, Vol. 23 No. 2, pp. 192-211.

Nnabugwu, F. (2015), "MSMEs employ 60millions Nigerians, accounts for 48\% of GDP", available at: https://www.vanguradngr.com/2015/05

OECD (2018), OECD Science, Technology and Innovation Outlook 2018, OECD Publishing, Paris.

Olugbenga, A.F., Lateef, A.O. and Yusuf, A.S. (2018), "Cooperative societies loan facilities and employment generation of small-scale businesses in Ondo State, Nigeria", Research Journal of Business and Economic Management, Vol. 1 No. 2, pp. 17-24.

Orser, B.J., Riding, A.L. and Manley, K. (2006), "Women entrepreneurs and financial capital", Entrepreneurship Theory and Practice, Vol. 30 No. 5, pp. 643-665.

Othman, M.N., Ghazali, E. and Sung, Y.S. (2006), "Graduate versus non-graduate entrepreneurs in urban Malaysia: some insights into entrepreneurial personality, company and family background differences", Journal of International Business and Entrepreneurship Development, Vol. 68 No. 1, pp. 90-108.

Padaki, M. (2018), “Creating job-creators in rural India!", NHRD Network Journal, Vol. 11 No. 1, pp. $45-48$.

Palmié, M., Wincent, J., Parida, V. and Caglar, U. (2020), “The evolution of the financial technology ecosystem: an introduction and agenda for future research on disruptive innovations in ecosystems", Technological Forecasting and Social Change, Vol. 151, p. 119779.

Pavlov, A., Poutziouris, P. and Soufani, K. (2004), "Evaluating flexibility in small firm financing", Journal of Entrepreneurial Finance and Business Ventures, Vol. 9 No. 1, pp. 73-97.

Petter, S., Straub, D. and Rai, A. (2007), "Specification and validation of formative constructs in IS research", MIS Quarterly, Vol. 31 No. 4, pp. 623-656.

Quartey, P., Turkson, E., Abor, Y. and Iddrisu, A.M. (2017), "Financing the growth of SMEs in Africa: what are the constraints to SME financing within ECOWAS?", Review of Development Finance, Vol. 7 No. 1, pp. 18-28.

Riding, A.L. and Swift, C.S. (1990), "Women business owners and terms of credit: some empirical findings of the Canadian experience”, Journal of Business Venturing, Vol. 5 No. 5, pp. 327-340, 0883-9026, doi: 10.1016/0883-9026(90)90009-I.

Robb, A.M. (2002), "Small business financing: difference between young and old firms", Journal of Entrepreneurial Finance, Vol. 7 No. 2, pp. 45-64. 
Rosavina, M. and Rahadi, R.A. (2018), "Peer-to-Peer (P2P) lending Platform adoption for small medium enterprises (SMEs): a preliminary study”, International Journal of Accounting, Vol. 3 No. 10, pp. 1-14.

Scott, J.M. and Irwin, D. (2009), "Discouraged advisees? The influence of gender, ethnicity and education in the use of advice and finance by UK SMEs", Environmental and Planning: Government and Policy, Vol. 27 No. 2, pp. 230-245.

Small and Medium Enterprise Development Agency of Nigeria (2013), SMEDAN and National Bureau of Statistics Collaborative Survey: Selected Findings.

Sogorb-Mira, F. (2005), "How SMEs uniqueness affects capital structure: evidence from a 1994-1998 Spanish data panel”, Small Business Economics, Springer, Vol. 25 No. 5, pp. 447-457.

Storey, D.J. (1994), Understanding the Small Business Sector, Routledge, London. doi: 10.4324/ 9781315544335.

Sykes, J., Elder, S., Gurbuzer, Y. and Principi, M. (2016), Exploring the Linkages between Youth Financial Inclusion and Job Creation: Evidence from the ILO School-To-Work Transition Surveys, Work 4 youth Publication Series. No 42, International Labour Office, Geneva.

Tabachnik, B.G. and Fidell, S.L. (2007), "Discriminant analysis", Using Multivariate Statistics, Vol. 6, pp. 377-438.

Tah, K.A. (2019), "Remittances and financial access: evidence from Sub-saharan Africa”, Cogent Economics and Finance, Vol. 7 No. 1, p. 1570581.

Taiwo, J.N., Falohun, T.O. and Agwu, M.N. (2016), "SMEs financing and its effect on the Nigeria economic growth", European Journal of Business, Economics and Accountancy, Vol. 4 No. 4, pp. 37-54.

Thorsten, B., Asli, D. and Maria-Soledad, M. (2007), "Reaching out: access to and use of banking services across countries”, Journal of Financial Economics, Vol. 85 No. 1, pp. 234-266, 0304405X, doi: 10.1016/j.jfineco.2006.07.002.

Tidjani, C. (2020), "Readiness to the FinTech industry in developing countries: an overview of prospective factors impacts", Handbook on Ethics in Finance, pp. 1-32.

Tirfe, A.G. and Abera, N. (2014), "Determinants of micro and small enterprise's access to finance", Developing County Studies, Vol. 4 No. 21, pp. 90-104.

Vasilescu, L.G. (2010). "Factoring-financing alternative for SMEs”, In 5th Annual MIDES International Conference, Kavala, pp. 13-23.

World Economic Forum (2017), The Global Competitiveness Report, Columbia University.

Wu, J., Song, J. and Zeng, C. (2008), "An empirical evidence of small business financing in China”, Management Research News, Vol. 31 No. 12, pp. 959-975.

Zarook, T., Rahman, M. and Khanam, R. (2013), "The impact of demographic factors on accessing finance in Libya's SMEs”, International Journal of Business Management, Vol. 8 No. 14, p. 55.

Zhang, G. (2008), "The choice of formal or informal finance: evidence from Chengdu, China”, China Economic Review, Vol. 19 No. 4, pp. 659-678.

\section{Corresponding author}

Oluyemi Theophilus Adeosun can be contacted at: oluyemiadeosun@gmail.com
Disruptive financial innovations

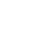

